\title{
Colour Vision Status of Staff Working with Radiation in Public Hospital
}

(Status Penglihatan Warna Pekerja yang Bekerja dengan Radiasi di Hospital Awam)

\author{
BARIAH MOHD-ALI*, WONG MEI YEE \& BASHIRAH ISHAK
}

\section{ABSTRACT}

Growing application of radiation sources and lack of awareness among workers in practicing protective measures imply an increased risk of radiation exposure to eye. This study determined the status of colour vision and its association with working duration amongst staff working with radiation in a university hospital. A total of 55 employees (28 exposed (RS) and 27 not directly exposed to radiation (NRS)) were recruited and 30 employees were used as controls. Visual acuity (VA) was measured using Snellen chart. Colour vision assessments were conducted using Ishihara plates, D15 panel and FM 100 hues and the results were analysed using one way ANOVA. The subjects' age ranged between 29 and 44 years old. Mean VA for all subjects was 6/6. More than 50\% of the subjects has colour defects, $3.45 \%$ of RS failed D15, 37.93\% failed FM 100 hue, 7.4\% of NRS failed D15 and 55.56\% failed FM 100 hue. Significant difference was found in the total error scores between RS (77.10 \pm 6.05$)$ and NRS $(84.89 \pm 7.76)$ with the controls $(41.47 \pm 3.10)$ [ANOVA F $(2,83)=16.084$, $p=0.00]$. There was no association between working duration and severity of colour defect $[r(104)=-0.123, p>0.05]$. This study concludes that majority of the studied subjects has color deficiency but not significantly correlated with their working duration. Protective measures need to be taken to improve the situation.

Keywords: Colour defect; colour perception; occupational radiation exposure

\section{ABSTRAK}

Pertambahan dalam aplikasi radiasi serta kurangnya kesedaran pekerja untuk menggunakan peralatan keselamatan menyebabkan risiko dedahan radiasi kepada mata meningkat. Kajian ini bertujuan untuk menentukan status penglihatan warna serta hubungannya dengan tempoh bekerja dalam kalangan kakitangan yang bekerja dengan radiasi di sebuah hospital universiti. Seramai 55 orang pekerja (28 terdedah secara terus (RS) dan 27 tidak terdedah secara terus (NRS)) terlibat dalam kajian ini dan 30 orang lagi digunakan sebagai subjek kawalan. Akuiti visual diukur menggunakan carta Snellen. Penglihatan warna diuji menggunakan plat Ishihara, panel D15 dan FM 100 hue. Keputusan kajian dianalisis menggunakan ANOVA sehala. Julat umur subjek adalah 29 hingga 44 tahun. Purata VA untuk semua subjek adalah 6/6. Lebih 50\% subjek mempunyai defek penglihatan warna, 3.45\% RS gagal ujian D15, 37.93\% gagal ujian FM 100 hue, 7.4\% NRS gagal ujian D15, 55.56\% gagal ujian FM 100 hue. Analisis menunjukkan perbezaan signifikan dalam skor total error antara $R S(77.10 \pm 6.05)$ dan NRS $(84.89 \pm 7.76)$ berbanding kawalan $(41.47 \pm 3.10)($ ANOVA $F(2,83)=16.084$, $p=0.00)$. Tiada hubungan didapati antara tempoh bekerja dengan keterukan penglihatan warna $(r(104)=-0.123, p>0.05)$. Kajian ini menyimpulkan kebanyakan kakitangan kajian mempunyai kecacatan penglihatan warna tetapi ia tidak berkait dengan tempoh bekerja. Langkah keselamatan perlu diambil untuk memperbaiki keadaan tersebut.

Kata kunci: Dedahan radiasi; kecacatan warna; persepsi warna

\section{INTRODUCTION}

The use of radiation in the health sector has increased significantly particularly in the use of new technologies such as computed tomography (CT) and magnetic resonance imaging (MRI) (Smith-Bindman et al. 2012). Even though the exposure to high dose ionising radiation is rare outside radiotherapy, repeated exposure to moderate and low dose radiation is becoming increasingly common with medical radiation being the largest contributor. Repeated exposures to moderate and low doses of radiation has shown to be an established risk factor for cancer and cataract. Leuraud et al. (2015) showed positive correlation between cumulative dose of ionising radiation and death by leukemia, with the greatest association for chronic myeloid leukemia. Multiple epidemiological studies from Japan have shown positive correlation between low-dose radiation exposures and induced cataract (Ainsbury et al. 2009).

Apart from crystalline lens, the neurosensory cells in the retina are also extremely vulnerable to the ionising radiation. Any functional disturbance of rods and cones in the retina will disrupt the photopic, scotopic as well as color vision (Lessel 2004). Congenital colour vision deficiencies result from inherited photo pigment abnormalities and the most common form is due to abnormal responses to red-green stimuli, originating from an abnormal function long wavelength sensitive photo pigment (protan-type anomalies) or intermediate wavelength sensitive (deutantype) photo pigment. A less frequent type of chromatic 
anomaly is absent or abnormal short wavelength sensitive photo pigment (tritan-type). Congenital red-green colour vision deficiencies has a X-linked type of inheritance (Piantanida 1991) and the prevalence is approximately $8 \%$ in males and $0.4 \%$ in females (Birch 1993).

Unlike congenital defects, acquired color vision deficiencies are evenly distributed between males and females (Pacheco-Cutillas 1999). Acquired deficiencies can be attributed to a number of different causes: alteration of pre-receptoral filters, reduced cone photo pigment optical density, greater loss of one cone type than the others, and disruption of post-receptoral processes. Blue defects are usually acquired defects because congenital tritan defects have an incidence of one in several tens of thousands.

Earlier studies have shown that occupational radiation exposure has potentially induce subtle reduction in color discrimination among health/medical employees due to their profession (Bashirah et al. 2000). In Malaysia, Bashirah et al. (2000) investigated colour vision status of staff working in the radiology department in a public hospital in Kuala Lumpur and reported that $53.6 \%$ of the radiographers and $55 \%$ of the support staff (not directly exposed to radiation) failed the FM 100 hue test. The results showed poor hue discrimination particularly in the blueyellow axis indicating the possibility of radiation exposure during work.

Colour vision assessment has been used in many situations such as to diagnose some ocular diseases, particularly in the early stage (Pacheco-Cutillas 1999; Pengiran Suhaili et al. 2010) to determine the impact of chemical exposure at work place (Sharanjeet-Kaur et al. 2004) and to verify the visual status of car drivers (Haliza et al. 2011, 2010). This cross sectional clinical study was planned to determine the status of colour vision and its association with working duration amongst staff working with radiation in a public university hospital.

\section{MATERIALS AND METHODS}

A total of 68 staff from Radiology Department, Faculty of Medicine and 30 employees from Faculty of Health Science, Universiti Kebangsaan Malaysia (UKM) volunteered to participate in this study. The staff from Faculty of Health Science were never exposed to work related radiation during time of the study and was treated as the control group. The inclusion criteria included age between 20 and 45 years old, best corrected visual acuity $\geq 6 / 9$, best near corrected acuity $\geq N 6$ at $40 \mathrm{~cm}$, no congenital colour defect, not taking any neurotoxic drugs for more than 12 months, free from any ocular and systemic disease, no history of occupational chemical exposure, alcohol consumption or smoking. Only those who fulfil the inclusion criteria will proceed to colour vision testing. The research protocol was approved by the institutional ethical review board (UKM 1 .5.3.5/244/NN015-2014) and adhered to the tenets of the Declaration of Helsinki. Informed consent was obtained from each subject before participants and possible consequences of the study were fully explained.

\section{OCULAR EXAMINATION}

Subjective refraction was conducted on both eyes using cross cylinder technique and visual acuity (VA) measurement was done using Snellen chart for distance and UKM near chart for near. Fundus examination was conducted using direct Ophthalmoscopy. Subjects who fulfilled the inclusion criteria will proceed to the colour vision examination.

Colour vision testing was conducted using a combination of pseudochromatic plates and hue arrangement tests that included Ishihara Plate edition 36, Farnsworth D15 Saturated 5/4 (D15), FarnsworthMunsell 100 hue (FM 100 hue). The Ishihara plates are recommended as screening plates for congenital red-green defects (10). Subjects who made less than 4 errors on the Ishihara plates are considered normal. The D15 and FM100 Hue tests can differentiate the type and severity of any colour vision defect (Fletcher \& Voke 1985). Both tests are arrangement colour test where subjects were asked to arrange the movable colour caps with natural progression beginning with the fixed cap. In FM100 Hue test, the caps are grouped into 4 boxes. In each box, two caps are fixed and the patient is asked to arrange the remaining ones to form a gradual progression between the two fixed caps.

Subjects who passed the Ishihara test continued with the D15 and FM100 hue tests. Subjects wore their best correction while doing the test at $35-40 \mathrm{~cm}$ away with viewing angle of approximately $35^{\circ}-40^{\circ}$ from the plane of the colour vision test. The illumination was set up to be at $6500 \mathrm{~K}$ colour temperature and colour rendering index of 90 using Philips Fluotone Lifemax TL-D 36W/54. Detailed explanation of the study and test procedure was given to subjects prior to testing. The testing procedures and conditions were similar for all 3 groups.

The analysis used for the D-15 and FM100 Hue tests was that of Vingrys and King-Smith (Vingrys \& KingsSmith 1988). This method of analysis is based on colour difference vectors, where the angle of maximum radius identifies the primary axis of colour confusion. The Vingry's program automatically indicates the presence of specific protan, deutan and tritan axes of confusion after processing the cap arrangement of each subject. The length of the maximum radius gives an estimate of the error score via the confusion index (C-index), which is derived by dividing the length of a subject's maximum radius by the maximum radius obtained for a perfect arrangement of caps.

Normality of data was tested using Shapiro-Wilk test $(p>0.05)$. One Way ANOVA (Analysis of Variance) was used to compare the total error score (TES) between subjects whereas the Spearman Correlation test was used to determine the relationship between working duration and total TES. 


\section{RESULTS AND DISCUSSION}

A total of 68 employee of the Radiology Department, Faculty of Medicine, UKM agreed to participate in the study but only 60 of them fitted the inclusion criteria. Four of them stopped half way during the examination due to work commitments and therefore the final number of subjects participated in the study was 55 . The subjects were later divided to 2 groups; the radiation (RS) and nonradiation groups (NRS) for analysis purposes. The RS group consisted of subjects who were directly exposed to work related radiation such as the radiographers and the NRS group consisted of subjects who were not directly exposed to work related radiation such as the nurses and clerical staff. A total of 28 subjects were included in the RS group and 27 subjects were in NRS group.

Demographically, the RS group consisted of 28 (96.6\%) Malays and 1(3.4\%) Indian with 15 (53\%) males and $14(47 \%)$ females. In the NRS group, there was 22 $(81.5 \%)$ females and $5(18.5 \%)$ males of which $25(92.6 \%)$ of them are Malays, one (3.7\%) Chinese and one (3.7\%) Indian. The age range for all subjects was from 29 to 44 years. Mean age for RS was $32.07 \pm 1.20$ years and for NRS was $34.47 \pm 1.14$ years. Mean age for the control group was $33.17 \pm 1.01$ years. Statistical analysis showed no significant difference in age between these three groups $(p=0.09)$.

Regarding working duration, the mean of working years for RS, NRS and control groups was $8.03 \pm 1.05,6.57$ \pm 0.99 and $7.53 \pm 1.50$, respectively, and the statistical analysis yielded insignificant difference between all the groups $(p=0.04)$. The distribution of age, gender and race for all subjects summarized in Table 1.

All subjects have good vision at distance and near with mean VA of $1.05 \pm 0.06(6 / 6)$. Fundus examination using direct ophthalmoscope showed no abnormalities in all subjects. All subjects passed the Ishihara test before proceeding to the Farnsworth Saturated 5/4 (D15) and Farnsworth-Munsell 100 Hue (FM 100 Hue) tests.

The results from D15 showed that $3(5.36 \%)$ of the subjects (1 RS, 2 NRS) had color vision deficiencies. Two subjects (1 RS, 1 NRS) were diagnosed as having diffuse or complex colour discrimination in both eyes and another subject (NRS) had blue colour deficiency. None of the subjects in control group had any color vision deficiencies. The results from Farnsworth-Munsell 100 Hue (FM 100 hue) showed that $26(46.4 \%)$ subjects were detected with color vision deficiencies. Eleven $(37.93 \%)$ of them were from RS group with $2(6.90 \%)$ of them were diagnosed as having blue colour deficiency and 9 of them (31.03\%) with diffuse or complex color discrimination. Color vision deficiency was also noted in $15(55.56 \%)$ subjects from NRS group, with 1(3.7\%) having subtle change in the blueyellow confusion axis and 14(51.87\%) with complex color discrimination. The results are summarised in Table 2.

The measured TES for RS group ranged from 15-149 (mean 77.10 \pm 6.05 ) and for the NRS group was from 4-160 (mean $84.89 \pm 7.76)$. The range of TES for control group was from 8-74 (mean $41.47 \pm 3.10$ ). The TES values were compared using one way ANOVA and the analysis showed significant difference between the three groups [ANOVA $\mathrm{F}(2,83)=16.084, p=0.00]$. Post Hoc test showed significant difference between both study group and control subjects. Both RS and NRS groups scored higher TES values than the control group. To determine the association between the working duration and colour vision deficiency, correlation analysis was performed using Spearman Rho. The analysis showed positive but insignificant correlation between working duration of the subjects and TES values $(\mathrm{r}(104)=$ $0.123, p>0.05$ ).

The results from the present study found that the majority of the staff who worked in the Radiology Department have colour vision defects. The number of subjects with colour vision defect was larger when tested with FM 100 hue than D15, confirming higher sensitivity of FM 100 hue in detecting acquired colour vision defects (Bashirah et al. 2000). The percentage of complex color defect $(31 \%, n=9)$ was undoubtedly higher than tritan defect $(6.9 \%, n=2)$ among the employees working in the radiation environment (RS). The percentage of complex colour defect and TES score seemed to be higher among those who were less exposed to work-related radiation (NRS) than those who were exposed to work-related radiation regularly (RS). One possible explanation is due to the unequal age distribution between groups. Majority of the subjects in the NRS group were older (40's) than those in the RS group (30's). According to Verriest et al. (1982) the TES score for normal population increases with decade of life. Their results showed that the TES score at $95 \% \mathrm{CI}$ for ages between 20-29 years, 30-39 years and 40-49 years is 107,133 and 188 , respectively. Hence, it is possible that age difference is a factor that contributed to the higher TES score in the NRS than RS group in this study.

TABLE 1. Demographic distribution of subjects

\begin{tabular}{lccccc}
\hline & $\mathrm{N}$ & \multicolumn{2}{c}{ Gender } & Mean age & $\begin{array}{c}\text { Duration of } \\
\text { working (years) }\end{array}$ \\
& & Male & Female & (years) & w.03 \\
\hline Directly exposed to radiation (RS) & 28 & 14 & 14 & $32.07 \pm 1.20$ & $8.03 \pm 1.05$ \\
Not directly exposed to radiation (NRS) & 27 & 5 & 22 & $34.37 \pm 1.14$ & $6.57 \pm 0.99$ \\
Control group & 30 & 10 & 20 & $33.17 \pm 1.01$ & $7.53 \pm 1.50$ \\
\hline TOTAL & 85 & 29 & 56 & & \\
\hline
\end{tabular}


TABLE 2. Summary of colour vision defects detected from 3 different tests

\begin{tabular}{lccc}
\hline & $\begin{array}{c}\text { Directly exposed to } \\
\text { radiation (RS) } \\
(\mathrm{N})\end{array}$ & $\begin{array}{c}\text { Not directly exposed } \\
\text { to radiation (NRS) } \\
(\mathrm{N})\end{array}$ & $\begin{array}{c}\text { Control group } \\
(\mathrm{N})\end{array}$ \\
\hline Ishihara & 0 & 0 & 0 \\
Farnsworth Saturated 5/4 (D15) & 1 & 2 & 0 \\
Farnsworth-Munsell 100 Hue (FM100 Hue) & 11 & 15 & 0 \\
\hline Mean TES Score & $77.10 \pm 6.05$ & $84.89 \pm 7.76$ & $41.47 \pm 3.10$ \\
\hline
\end{tabular}

With regards to association between working duration and colour deficiency, the results of this study showed positive but insignificant correlation, which was probably due to the small number of subjects. The cumulative dosage of radiation exposure as the working duration increases has a direct effect on the severity or degree of color deficiency (Frennesson \& Bergen 1998). However, we were unable to determine the accurate quantitative measurements of radiation exposure of each staff due to unreliable use of film badge by some of the employees. Several employees did not use the film badge provided by the management when working in a radiation environment. There were also few staff who did not return their film badge for periodical examination of total radiation exposure by the management. Regular monitoring system on the use of film bagde is needed to ensure the safety of the workers in the department.

The results of this study showed that exposure to radiation (directly or indirectly) in a working environment is associated with colour vision deficiency. The nature of colour vision testing allows some flexibility in the diagnosis because different clinical test probes into different aspects of colour perception (Aspinall 1974). According to Bresnick and Paltar (1987), tritan defects in certain systemic illnesses (such as diabetes) can become complex and demonstrate non-polar arrangements due to progressive deterioration from outer retinal layers to the optic nerve. The progressive damage will transform blueyellow defect to complex type of color deficiency. Thus, the observation in this study could reflect similar trend of progression in the severity of acquired colour defect. The observation is also supported by the significantly higher TES score in both study groups than the control subjects, which was similar to the earlier report on diabetic subjects (Bresnick \& Paltar 1987).

This present results supported an earlier study conducted by Bashirah et al. (2000) on a group of employees working in a radiation environment in a public hospital in Kuala Lumpur. In their study, no significant difference of color discrimination was noted between the two groups (RS and NRS) of subjects. Even though the exposure of assisting staff and nurses was reported to be low and 2 $\mathrm{mSv} /$ per case lesser than radiographer (Jindal 2013) as they were placed at longer distance from the radiation source, probability for stochastic effect (independent of dose) still exists and both groups possess the same risks to gain acquired color defect (Hellawel et al. 2005).
There was an assumption made in this study whereby the control group was free from medical or diagnostic radiation. It has been reported that the total effective dose from natural radiation source such as cosmic ray, radioactivity from soil and food for an individual was estimated at a range of 1-10 $\mathrm{mSv}$ while the effective dos from medical source was at a range of 0 -several tens mSv (Grasty \& La Marre 2004). Further deterioration of hue discrimination among employees in the Radiology Department as compared to control group indicated that the medical exposure of radiation on top of natural radiation has an undeniable impact on color recognisation ability among employees involved in radiation application, although all of the subjects have not encountered problem in recognizing color in daily life.

Effectiveness of FM100 hue in detecting color impairment was noted in this study. The test successfully detected 26 out of 55 employees who encountered reduction in color recognisation and deficiency while D15 test detected only 3 of them with colour defeciency. FM100 hue is the most effective clinical test to detect acquired color deficiency and that D15 test is not as sensitive enough due to the large chromaticity step and reliable error score that was unable to be included in the calculation (Bashirah et al. 2000).

\section{CONCLUSION}

This study concludes that majority of the staff working in the radiology department has colour deficiencies but not significantly associated with their working duration. Awareness program and better monitoring system are needed to ensure their safety while working with radiation.

\section{ACKNOWLEDGEMENTS}

The authors acknowledged the cooperation of the staff of Radiology Department, Faculty of Medicine and Faculty of Health Science, UKM, Kuala Lumpur.

\section{REFERENCES}

Ainsbury, E.A., Bouffler, D. \& Dorr, W. 2009. Radiation cataractogenesis: A review of recent studies. Radiat. Res. 172: 1-9.

Aspinall, P.A. 1974. Some methodological problems in testing visual function. Mod. Probl. Ophthalmol. 13: 2-7. 
Bashirah, I., Sharanjeet, K. \& Ariffin, A.E. 2000. Dos dedahan radiasi dan penglihatan warna pekerja di MINT. Bulletin Kesihatan Masyarakat Isu Khas. pp. 129-134.

Birch, J. 1993. Clinical test design and examination procedure. In Diagnosis of Defective Colour Vision, edited by Foster, D.H. Oxford: Butterworth-Heinemann. pp. 53-70.

Bresnick, G.H. \& Palta, M. 1987. Predicting progression to severe proliferative diabetic retinopathy. Arch. Ophthalmol. 105: 810-814.

Fletcher, R. \& Voke, J. 1985. Defective Colour Vision: Fundamentals, Diagnosis And Management. Bristol: Adam Hilger Ltd.

Frennesson, C. \& Bergen, J. 1998. Retinal function in Swedish ophthalmologists using argon lasers as reflected in colour contrast sensitivity. Normal thresholds in the great majority of the cases. Acta Ophthalmol. Scandi. 78: 610-612.

Grasty, R.L. \& La Marre, J.R. 2004. The annual effective dose from natural sources of ionising radiation in Canada. Radiat. Prot. Dosimetry 108(3): 215-226.

Haliza, A.M., Md Muziman Syah, M.M.S. \& Norliza, M.F. 2011. Effectiveness of computerized visual screening tool used in driving schools in Malaysia. Malays. Fam. Physician 6: $15-18$.

Haliza,A.M., Md Muziman Syah, M.M.S. \& Norliza, M.F. 2010. Visual problems of new Malaysian drivers. Malays. Fam. Physician 5(2): 95-98.

Hellawel, G.O., Mutch, S.J., Thevendran, G., Wells, E. \& Morgan, R.J. 2005. Radiation exposure and radiologist: What are the risks? J. Urol. 174: 948-952.

Jindal, T. 2013. The risk of radiation exposure to assisting staff in urological procedures: A literature review. Urol. Nurs. 33: $136-139$.

Lessel, S. 2004. Friendly fire: Neurogenic visual loss from radiation therapy. J. Neuro-Ophthal. 24: 243-250.

Leuraud, K., Richardson, D.B., Cardis, E., Daniels, R.D., Gillies, M., O’Hagan, J.A., Hamra, G.B., Haylock, R., Laurier, D., Moissonnier, M., Schubauer-Berigan, M.K., Thierry-Chef, I. \& Kesminiene, A. 2015. Ionising radiation and risk of death from leukaemia and lymphoma in radiation-monitored workers (INWORKS): An international cohort study. Lancet Haematol. 2: e276-e281.
Pacheco-Cutillas, M., Sahraie, A. \& Edgar, D.F. 1999. Acquired colour vision defects in glaucoma-their detection and clinical significance. Br. J. Ophthalmol. 83: 1396-1402.

Pengiran Suhaili, D.N., Goh, B.S. \& Gendeh, B.S. 2010. A ten year retrospective review of orbital complications secondary to acute sinusitis in children. Med. J. Malaysia 65: 49-52.

Piantanida, T. 1991. Genetics of colour vision deficiencies. In Inherited and Acquired Colour Vision Deficiencies, edited by Foster, D.H. London: MacMillan. pp. 88-114.

Sharanjeet-Kaur, Mursyid, A., Afifah, K. \& Azrin, A. 2004. Effects of petroleum derivatives on colour perception. Clin. Exp. Optom. 87: 339-343.

Smith-Bindman, R., Miglioretti, D.L., Johnson, E., Lee, C., Heather, S.F., Flynn, M., Greenlee, R.T., Kruger, R.L., Hornbrook, M.C., Roblin, D., Solberg, L.I., Vanneman, N., Weinmann, S. \& Williams, A.E. 2012. Use of diagnostic imaging studies and associated radiation exposure for patients enrolled in large integrated health care systems, 1996-2010. JAMA 307: 2400-2409.

Verriest, G., Laetherm, J.V. \& Uvijls, A. 1982. A new assessment of the normal ranges of the Farnsworth-Munsell 100-hue test scores. Am. J. Ophthalmol. 93(5): 635-642.

Vingrys, A.J. \& King-Smith, P.E. 1988. A quantitative scoring technique for panel tests of colour vision. Invest Ophthalmol Vis. Sci. 29: 50-63.

Optometry and Vision Science Program

School of Healthcare Sciences, Faculty of Health Science

Universiti Kebangsaan Malaysia

Jalan Raja Muda Abdul Aziz

50300 Kuala Lumpur, Federal Territory

Malaysia

*Corresponding author; email: bariah@ukm.edu.my

Received: 30 January 2018

Accepted: 5 June 2018 